\title{
Charcoal Dispersal from Alpine Stállo Hearths in Sub-Arctic Sweden: Patterns Observed from Soil Analysis and Experimental Burning
}

\author{
Greger Hörnberg ${ }^{1} \&$ Lars Liedgren ${ }^{1}$ \\ ${ }^{1}$ The Institute for Sub-Arctic Landscape Research, Arjeplog, Sweden \\ Correspondence: Greger Hörnberg, The Institute for Sub-Arctic Landscape Research, Torget, SE-93090 \\ Arjeplog, Sweden. Tel: 46-961-145-02. E-mail: greger.hornberg@silvermuseet.se
}

Received: December 8, 2011 Accepted: January 14, 2012 Online Published: July 1, 2012

doi:10.5539/ach.v4n2p29

URL: http://dx.doi.org/10.5539/ach.v4n2p29

The study has been financed by the European Regional Development Fund.

\begin{abstract}
To evaluate dispersal patterns and concentrations of macroscopic charcoal particles around Stállo settlements in sub-arctic Scandinavia, their distributions following experimental burning and soil concentrations around an alpine Stállo settlement dating between AD 700 and 1150 were recorded. After the burning $98 \%$ of recorded particles were $0.1-0.5 \mathrm{~mm}$ long, $90 \%$ were dispersed within $40 \mathrm{~m}$ of the fire, their mean concentration $40 \mathrm{~m}$ from the fire was $0.14 \pm 0.08$ particles $/ \mathrm{cm}^{2}$ and the concentration decreased with increasing distance. At the settlement, $95 \%$ of recorded charcoal particles were $0.1-0.5 \mathrm{~mm}$ long, $94 \%$ were within $40 \mathrm{~m}$ of the hearths, the mean concentration declined with increasing distance, and concentrations were much lower than expected from the experimental burning (e.g. $17.6 \pm 2.4$ particles $/ \mathrm{cm}^{2}, 40 \mathrm{~m}$ away). In conclusion: biological archives used for charcoal analysis in archaeological and vegetation history studies should be located $\leq 40 \mathrm{~m}$ from settlements, and data obtained from charcoal analyses should be interpreted cautiously.
\end{abstract}

Keywords: archaeology, macroscopic charcoal, multidisciplinary, Scandinavia, sub-alpine settlement

\section{Introduction}

\subsection{Charcoal in Archaeological and Fire Ecology Studies}

Charcoal found associated with archaeological sites is generally interpreted as originating from anthropogenic fires, such as large-scale burnings of vegetation to: increase the growth of grasses and herbs, and thus attract wild game (Mellars, 1976, Hörnberg et al., 1999); provide grazing for domestic animals (Emanuelsson \& Segerström, 1998); or clear areas around settlements for construction and cultivation, e.g. in slash and burn cultivation (Wallin \& Segerström, 1994, Larsson, 1995, Emanuelsson, 2001). In addition, small fires, utilized to keep huts warm and prepare food, also produced charcoal (Bennett et al., 1990, Hörnberg et al., 2006, Sergant et al., 2006, Liedgren et al., 2007). However, in many environments, such as the boreal forest, natural fire is an important and recurrent factor (Zackrisson, 1977, Heinselman, 1981). Consequently, it can be difficult to determine if the charcoal recorded at archaeological sites derives from anthropogenic or natural fires (Théry-Parisot et al., 2010). This has also made it difficult to date ancient boreal settlements using charcoal because old particles may have combusted and new ones may have been produced by numerous natural fires that have affected the settlement area before and after their use (Liedgren et al., 2007).

In long-term fire ecology studies, peaks in microscopic $(<0.1 \mathrm{~mm})$ and macroscopic charcoal $(>0.1 \mathrm{~mm})$ particles from biological archives, such as lake sediments and peat mires, have been interpreted as indicating fire events (Patterson et al., 1987, Whitlock \& Millspaugh, 1996, Tinner \& Hu, 2003), especially if the peaks co-occur with changes in vegetation detected by pollen analysis (Segerström et al., 2008, Hörnberg et al., 2012). Numerous studies have examined the amounts of charcoal produced by forest fires (Clark et al., 1998, Lynch et al., 2004, Froyd, 2006, Carcaillet et al., 2007, Ohlson et al., 2009) and evaluated the methods used (Preston \& Schmidt, 2006, Ali et al., 2009, Schalachter \& Horn, 2010, Mooney \& Tinner, 2011). Several theoretical models have also been developed to assess regional forest fire patterns, natural fire frequencies and to separate regional 
and local fire events (Clark, 1988, Higuera et al., 2007, Peters \& Higuera, 2007). However, despite all the new approaches and techniques applied in both fire ecology and archaeology, the interpretation of charcoal occurrences is still problematic because it is difficult to distinguish charcoal produced by local fires from the background influx created by regional fires. In addition, it is challenging to establish whether recorded charcoal derives from man-made or natural fires (Clark, 1988, Lynch et al., 2004, Théry-Parisot et al., 2010).

However, archaeological analyses in areas where there have been few natural fires provide opportunities to identify the impact of man on local burning, especially if charcoal co-occurs with sites of human activity. The sub-alpine and alpine areas of the Scandinavian Mountain range are located at high altitudes where the climate is humid. Precipitation exceeds evaporation due to low temperatures and the region has a short period of vegetation growth (Sjörs, 1999). There are very few natural fires due to lightning strikes in these regions (Granström, 1993). Thus, any particles of charcoal found in association with archaeological settlements in these zones are very likely to have originated from local anthropogenic burnings.

\subsection{Stállo Settlements in the Scandinavian Mountains}

Stállo settlement remains are found throughout the sub-alpine and alpine zone in the northern part of the Scandinavian Mountain range, often at altitudes below the average current forest line for the region. These remains consist of foundations characterized by a flat sunken floor surrounded by a low soil embankment with a stone-built hearth in the middle, often occurring in groups with three to five foundations in a row (Kjellström, 1983, Mulk, 1994, Bergman et al., 2007). On each foundation a small hut-like Stállo building is thought to have stood, probably constructed of birch stems and birch bark with a smoke hole in the roof (Liedgren \& Bergman, 2009). In accordance with this construction hypothesis, analyses of charcoal collected from Stállo hearths by Hellberg (2004) showed that it predominantly (94\%) originated from mountain birch (Betula pubescens ssp. czerepanovii), based on identification criteria described by Hellberg and Carcaillet (2003), indicating that the settlers used this wood for firewood. Pollen analyses have also shown that mountain birch forests around Stállo settlements in four different areas were cut (Karlsson et al., 2007; 2009, Staland et al., 2011). However, no remains of these buildings exist today, apart from the foundations. In a multidisciplinary study of such Stállo settlements in northern Sweden, extensive dating of the charcoal found in the hearths indicated that these

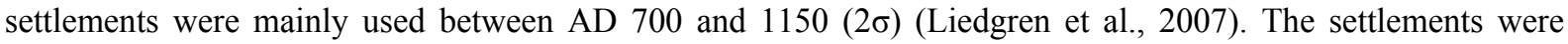
eventually completely abandoned, probably due to a shortage of firewood, and the lack of trees combined with a colder climate during the Little Ice Age subsequently prevented reforestation (Karlsson et al., 2007; 2009, Staland et al., 2011). Hence, the vegetation changed from mountain birch forest with herbs to open alpine heath dominated by dwarf-shrubs due to human exploitation, nutrient-depleted soils and the harsh climate (Staland et al., 2011). The presence of solitary tent hearths also indicates that most of these areas were visited sporadically after the Stállo period by nomadic visitors who probably used the last remnants of trees, shrubs and dwarf-shrubs as fuel (Hellberg 2004). Still today many Stállo settlements are located in the alpine zone at an altitude below the average forest line for the region.

The peat cores from the Stállo settlements analyzed for pollen by Karlsson et al. $(2007 ; 2009)$ and Staland et al. (2011) were sampled from small mires located between 50 and $150 \mathrm{~m}$ from the nearest settlement. The cited authors expected to detect relatively large amounts of charcoal together with the pollen in samples dating from the Stállo period. However, they found very few microscopic charcoal particles, and they did not always co-occur with that period. The results also indicated that the overall frequency of natural fires had been very low. The findings raised several questions regarding why there were so few charcoal particles, the origins of the recorded particles, and the dispersal distances and distributions of charcoal from hearths in Stállo huts. Fire ecology studies have shown that total numbers of charcoal, including large particles, decrease with increasing distance from the edge of a burnt forest area (Ohlson \& Tryterud, 2000). Thus, it seems reasonable to assume that the amount of charcoal dispersed from a Stállo hearth would be high close to the settlement and decrease with increasing distance, and that large particles would occur most frequently close to the hearths. If, in contrast, fire was used to clear the vegetation around the settlements, the amount of charcoal would be similar over a large area and particles of all sizes should appear in the soil at all distances from the settlement within that area. Additionally, if charcoal mainly originated from regional fires, small particles should pre-dominate, and they should be deposited fairly evenly over the area.

\subsection{Objectives}

The objectives of the study presented here were, consequently, to evaluate dispersal patterns of macroscopic charcoal from a Stállo hearth, and to record both the abundance and distribution of charcoal in the soil around an ancient alpine Stállo settlement with a known history. We addressed the following questions. Firstly, will 
sufficient charcoal be dispersed from a hearth inside a hut for it to be detectable in the vicinity of a settlement? Secondly, how far can charcoal produced in hearths disperse, and what is the resulting distribution pattern like? Thirdly, can fossil charcoal produced at the time of a Stállo settlement still be found in the soil around an alpine settlement today? Finally, based on the charcoal distribution pattern, is it possible to ascertain whether the particles derived from a hearth fire, from burning vegetation or from regional fires? To address these questions, an experimental burning was conducted and soil samples were collected from the surroundings of an ancient Stállo settlement with a known history.

\section{Material and Methods}

\subsection{Experimental Burning}

\subsubsection{Study Site, Precipitation, Temperature and Wind}

The field experiment took place over four consecutive days in February 2010 on a frozen lake in northern Sweden, Lake Hornavan $\left(66^{\circ} 04^{\prime} 37^{\prime}\right.$ 'N; $\left.17^{\circ} 55^{\prime} 62^{\prime \prime} \mathrm{E}\right)$, with 15 to $20 \mathrm{~cm}$ of snow cover. The study site is located c. $3 \mathrm{~km}$ from the small town of Arjeplog at $423 \mathrm{~m}$ above sea level (m a. s. 1.). The chosen site was far from the shoreline to provide optimal conditions for undisturbed charcoal dispersion. On the first day, a stick was placed on the ice and eight transects were established, extending $200 \mathrm{~m}$ in the cardinal (N, S, E and W) and ordinal (NE, NW, SE and SW) directions (Figure 1). Along each transect, samples of snow were collected at 5, 10, 20, 40, 60, $80,100,150$ and $200 \mathrm{~m}$ distances from the center stick to determine the amount of charcoal in the snow before the experimental burning started. These "reference" samples were collected $50 \mathrm{~cm}$ to the left of each transect when facing away from the stick. Each sample was collected using a plastic container $(20 \times 20 \mathrm{~cm}$ in area, $5 \mathrm{~cm}$ deep) that was pressed down into the snow. Along one edge of the container the snow was removed vertically by a flat clean shovel. The shovel was then carefully pressed horizontally against the container from the side to cover its open end, and thus collect the top $5 \mathrm{~cm}$ layer of snow. The collected snow was transferred into zip-lock bags that were tagged, placed in larger bags and kept in a cold storage room until analysis. In total, 72 reference samples were collected. A portable tent hut (Moskoselkåtan ${ }^{\circledR}$ Jakt 7) was erected with its center over the center stick (cf. Liedgren \& Östlund, 2011), and with a circular smoke hole (c. $40 \mathrm{~cm}$ in diameter) at a height of $2 \mathrm{~m}$ to simulate a Stállo hut building (cf. Liedgren \& Bergman, 2009).

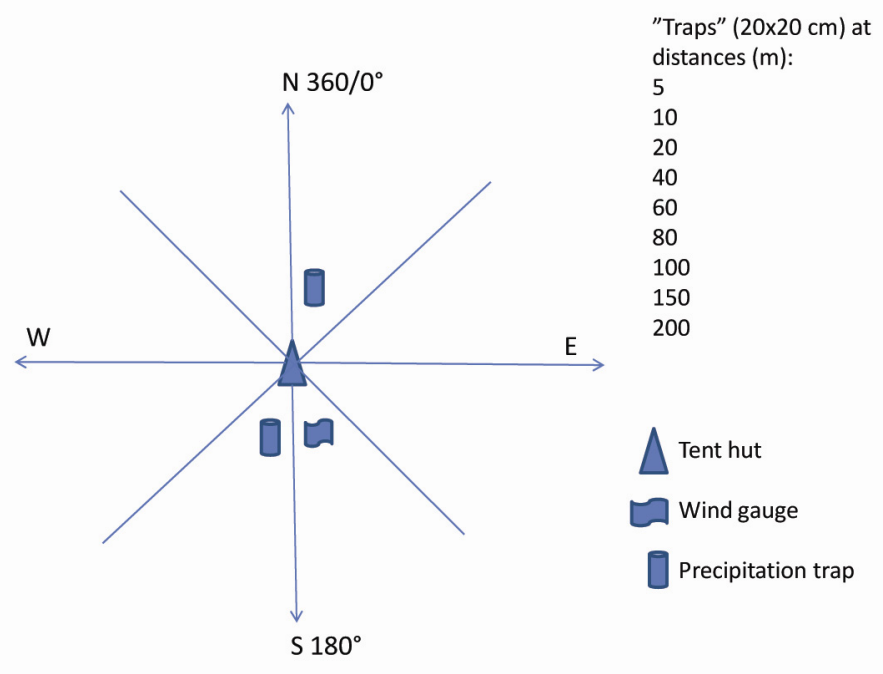

Figure 1. The design of the experimental burning with the hut in the centre, eight $200 \mathrm{~m}$ long transects, two precipitation traps and one wind gauge

On the morning of day two, two cylindrical containers with a $5.5 \mathrm{~cm}$ radius were placed $10 \mathrm{~m}$ away from the hut in two directions (Figure 1) to measure the precipitation during the two days of experimental burning. The containers were collected at the end of day three, and the mean precipitation collected was $4.6 \mathrm{~cm}$ of fallen snow. The snowfall was modest but steady during the entire time of burning. A wind gauge (Kestrel $2000^{\mathrm{TM}}$ ) mounted on a $1.3 \mathrm{~m}$ tall tripod was placed $10 \mathrm{~m}$ to the SSE of the hut (Figure 1). The air temperature $\left({ }^{\circ} \mathrm{C}\right.$ ), wind speed $(\mathrm{m} / \mathrm{s})$ and wind direction $\left(360^{\circ}\right.$ compass) was measured every 30 minutes between 8 am and $6 \mathrm{pm}$ during days two and three whilst the experimental burning was conducted. For each day, the mean temperature \pm standard error $(\mathrm{SE})$ was $-12.8 \pm 0.2^{\circ} \mathrm{C}\left(\min .=-14.3^{\circ} \mathrm{C}\right.$, max. $\left.=-11.0^{\circ} \mathrm{C}\right)$ and $-18.3 \pm 0.2^{\circ} \mathrm{C}\left(\min .=-20.9^{\circ} \mathrm{C}\right.$, max. $\left.=-17.3^{\circ} \mathrm{C}\right)$, 
the mean wind speed was $2.3 \pm 0.4 \mathrm{~m} / \mathrm{s}(\min .=1.8 \mathrm{~m} / \mathrm{s}, \max .=3.2 \mathrm{~m} / \mathrm{s}$,$) and 1.8 \pm 0.1 \mathrm{~m} / \mathrm{s}(\min .=1.4 \mathrm{~m} / \mathrm{s}, \max .=$ $2.5 \mathrm{~m} / \mathrm{s})$, and the wind direction $\left(360^{\circ}\right.$ compass) varied between $115^{\circ} \mathrm{E}$ and $70^{\circ} \mathrm{E}$, with mean values of $97.9 \pm 1.9^{\circ} \mathrm{E}$ and $91.1 \pm 3.0^{\circ} \mathrm{E}$, respectively. Data from the Swedish Meteorological and Hydrological Institute's station in Arjeplog (http://www.smhi.se) gave similar values for wind speed (1.8 and $1.3 \mathrm{~m} / \mathrm{s})$ and wind direction $\left(114^{\circ} \mathrm{E}\right.$ and $\left.71^{\circ} \mathrm{E}\right)$. However, the wind changed direction during the night after the burning, but before the charcoal samples were collected, from ca. $71^{\circ} \mathrm{E}$ to $16^{\circ} \mathrm{N}$.

\subsubsection{Experimental Burning, Wood Moisture Content and Wood Consumption}

The experimental burning was conducted for ten hours per day for two days. At 8 am on days two and three, a fire was lit in a metal container $(51 \times 3 \times 17 \mathrm{~cm})$ placed in the center of the hut. The container rested on four wooden stumps c. $20 \mathrm{~cm}$ above the ice so it did not melt through it. The fire was kept going between 8 am and 6 $\mathrm{pm}$, and air was allowed to enter the hut at three places along the hut floor. The fuel consisted of chopped, dried birch wood with a mean moisture content of $10.9 \pm 0.1 \%$. The wood was consumed during the two burning periods (20 hours in total) at a rate of $3.7 \mathrm{~kg} /$ hour, very similar to the birch wood consumption rate (c. 3.6 $\mathrm{kg}$ /hour) measured in a previous experimental burning in a Stállo hut during winter (Liedgren \& Östlund, 2011).

On the morning of day four, samples of snow were collected along the eight transects. Since it seems unlikely that charcoal travels far down into snow and the average amount of fallen snow was less than $5 \mathrm{~cm}$, the snow samples were expected to contain charred particles from the burning. The snow samples were collected in the same way as the reference samples, but they were taken $50 \mathrm{~cm}$ to the right of each transect when facing outwards from the center stick. This procedure minimised the risk of air turbulence around the "reference" pits interfering with the deposition of charcoal at the post-burning sampling sites. A total of 144 samples were collected, 72 reference samples and 72 potentially containing charcoal from the experimental burning.

\subsubsection{Charcoal Analysis}

In the laboratory, the collected snow samples were allowed to melt in their bags. The resulting water was poured into a cylindrical glass then a subsample was transferred to a petri dish and examined under a microscope at 16 and 40 times magnification to measure and count charcoal. Charcoal was identified as all black fragments that were brittle and fractured into splinters in the same way as reference birch wood charcoal. The particles were classified into three size classes: 0.1 to $0.5 \mathrm{~mm},>0.5$ to $1.0 \mathrm{~mm}$, and $>1.0 \mathrm{~mm}$ (longest axis). The procedure was repeated until the whole sample had been analyzed. The total numbers of charcoal particles detected were recorded, and the mean numbers \pm standard error $(\mathrm{SE})$ of particles per $\mathrm{cm}^{2}$ detected at each sampled distance and direction from the hut were calculated. Charcoal concentrations at different distances and directions were then compared using the nonparametric Kolmogorov-Smirnov (KS) two sample test (Lynch et al., 2004).

\subsection{Adamvalldá Stállo Site}

\subsubsection{Field Sampling}

Adamvalldá covers ca. $7 \mathrm{~km}^{2}$ and is located in the alpine zone between 640 and $760 \mathrm{~m}$ above sea level, the same altitude as the forest limits in the region (Figure 2). There are remains of 12 Stállo settlements in the area, each with one to five foundations dating from AD 700 to AD $1150(2 \sigma)$, along with solitary tent hearths dating predominantly from AD 1500 to the present day (Liedgren et al., 2007, Hellberg, 2004). Microscopic charcoal has been identified in pollen analyses of peat samples from a local small mire (Karlsson et al., 2007) located 150 $\mathrm{m} \mathrm{N}, 230 \mathrm{~m}$ WNW and $300 \mathrm{~m}$ NNE from three such alpine Stállo settlements (designated SMA 65, 103 and 51, respectively). These sites are situated on three adjacent plateaus, where there were also 22 solitary tent hearths (Figure 2). Microscopic charcoal recorded by Karlsson et al. (2007) originated predominantly from two time periods: ca. $1050 \mathrm{BC}$, and the post-Stállo period (c. AD 1350 and later); only two particles were recorded that originated from the Stállo period (AD 700 and AD 1150). The more recent ones clearly originated after AD 1350, indicating that they did not derive from burning during the Stállo settlement period (Karlsson et al., 2007).

The Stállo settlement designated SMA 51 (6701'20'’N, 16³6'43',E; Figure 2), was selected for the field survey because it is situated on a flat plateau. Its settlement and vegetation history have been thoroughly investigated, and its present biotic and abiotic conditions have been described (Liedgren, 2004, Liedgren et al., 2007, Karlsson et al., 2007). This Stállo settlement is located in the alpine zone at c. $680 \mathrm{~m}$ above sea level on a glaciofluvial sediment terrace with podsolized soil including a distinct light grey E horizon. The Stállo settlement consists of three foundations in a row with a hearth in each. They are orientated in a NNE/SSW direction, and the distance between the northernmost and southernmost foundation is $38 \mathrm{~m}$. Four transects were established at each cardinal point (N, E, S and W) in mid July 2011 (Figure 2). A center stick was placed in the central area of the three foundations, $2.5 \mathrm{~m} \mathrm{SE}$ of the outer wall of the middle foundation, from which three $80 \mathrm{~m}$ long transects were established (N, E and W). Pairs of soil plugs were collected using a soil auger $(\varnothing=2 \mathrm{~cm})$ 
along those transects at distances of 5, 10, 20,40 and $80 \mathrm{~m}$ from the centre point, one at each side of the transects within $20 \mathrm{~cm}$ of the transect line. For the south transect, plugs were only collected at distances of 5, 10, 20 and $40 \mathrm{~m}$ as there was a ravine to the south that made sampling at $80 \mathrm{~m}$ impossible (Figure 2). In addition, four plugs were collected at the centre point $(0 \mathrm{~m})$, two immediately to the north and two immediately to the south. Thus, in total, 42 samples were collected. All the plugs contained fresh vegetation, humus and the top centimeter of the mineral soil. The total depth of the organic material (fresh vegetation and humus) above the mineral soil was measured by a ruler, which indicated that its mean depth $\pm \mathrm{SE}$ was $29.3 \pm 1.9 \mathrm{~mm}(\mathrm{~min} .=10 \mathrm{~mm}, \max .=65 \mathrm{~mm})$. The plugs were put in tagged zip-lock bags and stored in a freezer at the laboratory. Before analysis, the plugs were dried for 24 hours at $+70^{\circ} \mathrm{C}$ to make them easier to cut.
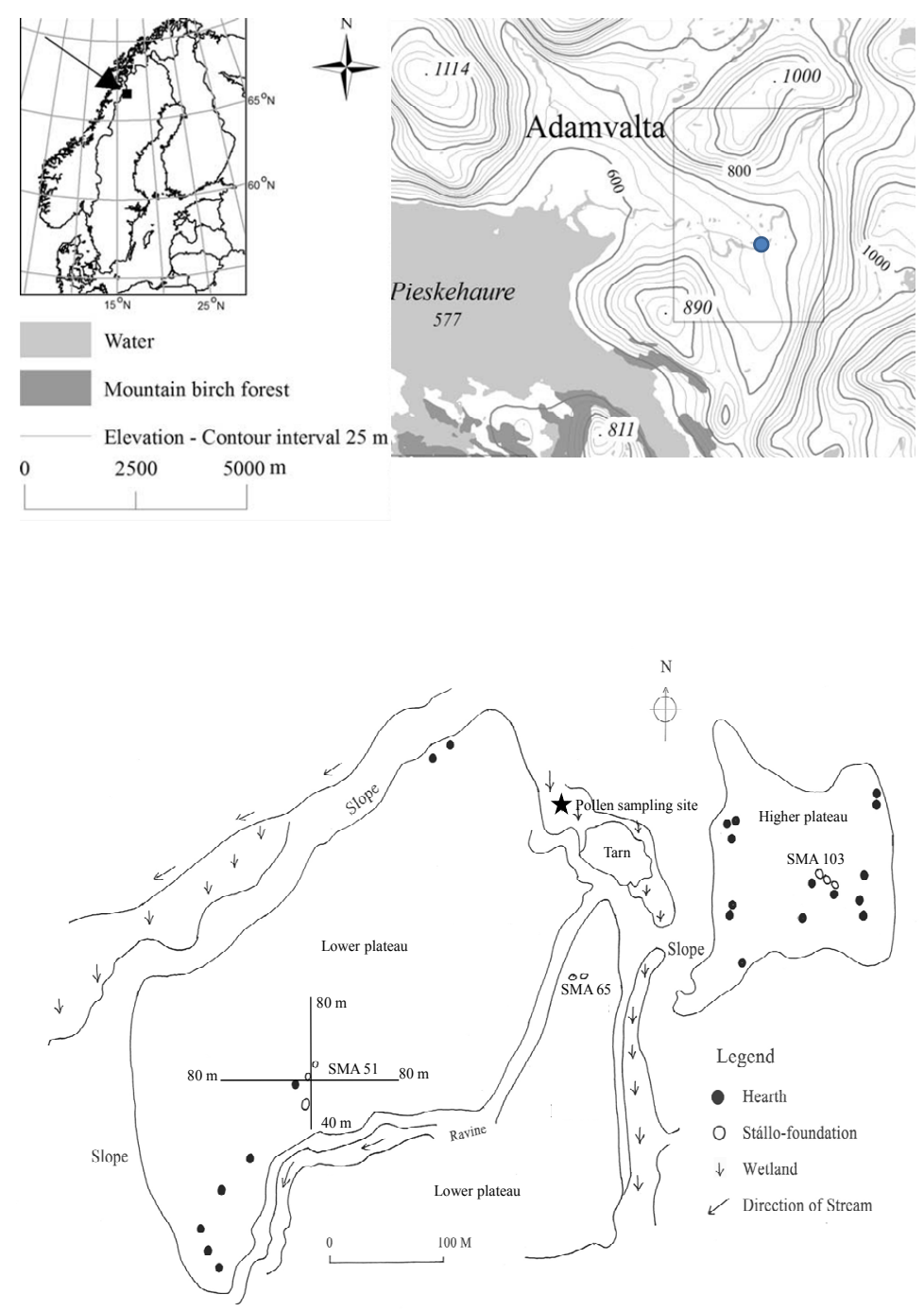

Figure 2. Top: Map of Sweden showing the study region (arrowed), a regional map of the Adamvállda (written as Adamvalta on the map) area indicated by a rectangle and the study site marked with a circle. Below: Sketch of the plateaus with three Stállo settlements and 22 solitary tent hearths. The three Stállo foundations at settlement SMA 51 are marked by open rings $(\mathrm{O})$ and the four transects along which parallel soil plugs were collected at 0 , 5, 10, 20, 40 and $80 \mathrm{~m}$ distances are marked by lines. The pollen sampling site used by Karlsson et al. (2007) is marked by a star

\subsubsection{Charcoal Analysis}

In the sub-arctic alpine zone, charcoal is concentrated in the topmost soil because bioturbation by soil fauna is low and restricted to the litter layer (Payette \& Filion, 1993, Carcaillet, 2001). The intact light grey E horizon 
also indicated that freeze-thaw processes caused no major turbulence in the soil, although its color indicated a downward movement of water and hence probably of microscopic charcoal particles. Decay of mountain birch tree-stumps from trees cut during the Stállo period, in what would become the alpine zone, may have caused some soil reworking. However, no evidence of such hiatus was observed in the soil samples collected from the Stállo settlement terrace. It seemed likely that macroscopic charcoal produced during the Stállo settlement period that had not fragmented into microscopic particles would be found predominantly in the transition zone between humus and mineral soil. Therefore, one slice of each plug was cut out using a scalpel comprising $2 \mathrm{~mm}$ of the light grey mineral soil and $8 \mathrm{~mm}$ of the mixed mineral-humus and humus layer (volume of each sample, 3.14 $\mathrm{cm}^{3}$ ). Consequently, macroscopic charcoal particles that may have been buried deeper in the soil were overlooked (Carcaillet, 2001). To minimize the risk of charcoal fragmentation through physical handling procedures, such as sieving or bleaching and degradation by strong chemical treatments (Schlater\& Horn, 2010), each sample was placed in a glass container with $20 \mathrm{ml}$ of $\mathrm{KOH}(5 \%)$ for 24 hours to loosen the humus. The material was carefully separated by hand using needles and tweezers (cf. Mooney \& Tinner, 2011). A subsample was transferred to a petri dish and water was added to dilute the dark solution. The charcoal particles were examined, measured and counted under a microscope at 16 and 40 times magnification in the same manner as the charcoal produced in the experimental burning, as described above. The procedure was repeated until the entire sample had been analyzed. Charcoal concentrations were then calculated, as the number of particles per $\mathrm{cm}^{2}$, at each sampled direction and distance. Charcoal concentrations at different distances were compared using the nonparametric KS two sample test (Lynch et al., 2004), and the mean values were compared using Student's t-test (Zar, 2010).

\section{Results}

\subsection{Experimental Burning}

\subsubsection{Charcoal Accumulation and Dispersal}

In total, the 72 reference samples collected prior to burning (each obtained from a $400 \mathrm{~cm}^{2}$ area) contained 219 particles, all between 0.1 and $0.5 \mathrm{~mm}$ long ( $\min .=0$, max. $=10$, mean $=3.0 \pm 0.2$ ), and c. $48 \%$ of all particles were found within $40 \mathrm{~m}$ of the settlement's center (Table 1). The total number of particles recorded after two days of burning was 2065 (min. $=0$, max. $=967$, mean $=28.6 \pm 14.2)$, of which $2021(98 \%)$ were $0.1-0.5 \mathrm{~mm}$ long, $40(1.9 \%)$ were $0.5-1 \mathrm{~mm}$ long, and four $(0.1 \%)$ were larger than $1 \mathrm{~mm}$. Over $90 \%$ of all charcoal particles were found within a radius of $40 \mathrm{~m}$ (Table 1), all particles between $0.5 \mathrm{~mm}$ and $1 \mathrm{~mm}$ were found within a radius of $20 \mathrm{~m}$ and all but one $>1 \mathrm{~mm}$ particle were recorded within $10 \mathrm{~m}$ of the hut.

Table 1. Percentages (concentrations, in numbers per $\mathrm{cm}^{2}$, in brackets) of charcoal particles (all sizes) at indicated distances from the centre stick, mean total deposition values (based on all data), and mean deposition values based on data obtained from samples collected at 5, 10, 20and $40 \mathrm{~m}$ distances in the Reference (Ref), Experimental burning (ExpB) and Stállo site (Stállo) analyses. Zero indicates the number of samples from the indicated distances in which no charcoal was detected ( $\mathrm{n}$ tot $=72$ for Ref and ExpB, and $\mathrm{n}$ tot $=42$ for Stállo).

\begin{tabular}{|c|c|c|c|c|c|c|}
\hline Distance $(\mathrm{m})$ & $\operatorname{Ref}(\%)$ & $\begin{array}{c}\text { ZeroRef } \\
\text { (n) }\end{array}$ & $\operatorname{ExpB}(\%)$ & $\begin{array}{c}\text { ZeroExpB } \\
\text { (n) }\end{array}$ & Stállo (\%) & $\begin{array}{c}\text { ZeroStállo } \\
(\mathrm{n})\end{array}$ \\
\hline 0 & - & - & - & - & 19.3 & 0 \\
\hline 5 & 11.9 & 1 & 55.6 & 0 & $20.2(39.5)$ & 0 \\
\hline 10 & $9.1(21.0)$ & 2 & $21.4(77.0)$ & 0 & $22.5(62.0)$ & 0 \\
\hline 20 & $11.0(32.0)$ & 0 & $6.6(83.6)$ & 0 & $20.0(82.0)$ & 0 \\
\hline 40 & $15.5(47.5)$ & 0 & $6.5(90.1)$ & 0 & $12.2(94.2)$ & 0 \\
\hline 60 & $10.5(58.0)$ & 0 & $2.4(92.5)$ & 2 & - & - \\
\hline 80 & $12.3(70.3)$ & 0 & $2.6(95.1)$ & 2 & $5.8(100)$ & 0 \\
\hline 100 & $7.3(77.6)$ & 1 & 1.8 (96.9) & 1 & - & - \\
\hline 150 & $11.0(88.6)$ & 1 & $2.0(98.9)$ & 0 & - & - \\
\hline 200 & $11.4(100)$ & 0 & $1.1(100)$ & 1 & - & - \\
\hline $\begin{array}{l}\text { Total mean } \pm \text { SE } \\
\qquad\left(\mathrm{n} / \mathrm{cm}^{2}\right)\end{array}$ & $0.0076 \pm 0.0006$ & & $0.072 \pm 0.036$ & & $17.9 \pm 2.3$ & \\
\hline $\begin{array}{c}5-40 \text { mean } \pm S E \\
\left(\mathrm{n} / \mathrm{cm}^{2}\right)\end{array}$ & $0.0027 \pm 0.0005$ & & $0.14 \pm 0.08$ & & $17.6 \pm 2.4$ & \\
\hline
\end{tabular}

The total concentration of charcoal in the snow prior to the experimental burning, according to analyses of the reference samples, varied between 0 and 0.025 particles $/ \mathrm{cm}^{2}$ with a mean of $0.0076 \pm 0.0006$ particles $/ \mathrm{cm}^{2}$ (Table 1). The charcoal was evenly distributed in terms of both distance (Figure 3a, Table 1) and direction from the 
center stick (Figure 3b). The total concentration of charcoal after two days of burning varied between 0 and 2.42 particles $/ \mathrm{cm}^{2}$ with a mean value of $0.072 \pm 0.036$ particles $/ \mathrm{cm}^{2}$ (Table 1 ). The concentrations were highest close to the hut, decreased with increasing distance (Figure 3a), and were highest along the west and south transects (Figure 3b). The mean concentrations at 150 and $200 \mathrm{~m}$ were $0.0128 \pm 0.0041$ and $0.0072 \pm 0.0029 \mathrm{particles} / \mathrm{cm}^{2}$, respectively. The particles were uniformly distributed in relation to distance from the hut in the reference samples, but they were not evenly distributed after the experimental burning (KS test, $\mathrm{D}_{\text {Ref }}=0.303196$ and $\left.\mathrm{D}_{\mathrm{ExpB}}=0.73624, \mathrm{D}_{0.001(2), 9}=0.60846\right)$. Data based solely on samples from 5, 10, 20 and $40 \mathrm{~m}$ distances pre- and post-burning gave mean charcoal concentrations of $0.0027 \pm 0.0005$ and $0.14 \pm 0.08$ particles $/ \mathrm{cm}^{2}$, respectively (Table 1). The particles were uniformly distributed before, but not after, the experimental burning (KS test, $\mathrm{D}_{\text {Ref40 }}=0.573077$ and $\left.\mathrm{D}_{\mathrm{ExpB} 40}=0.827918, \mathrm{D}_{0.002(2), 4}=0.82217\right)$.
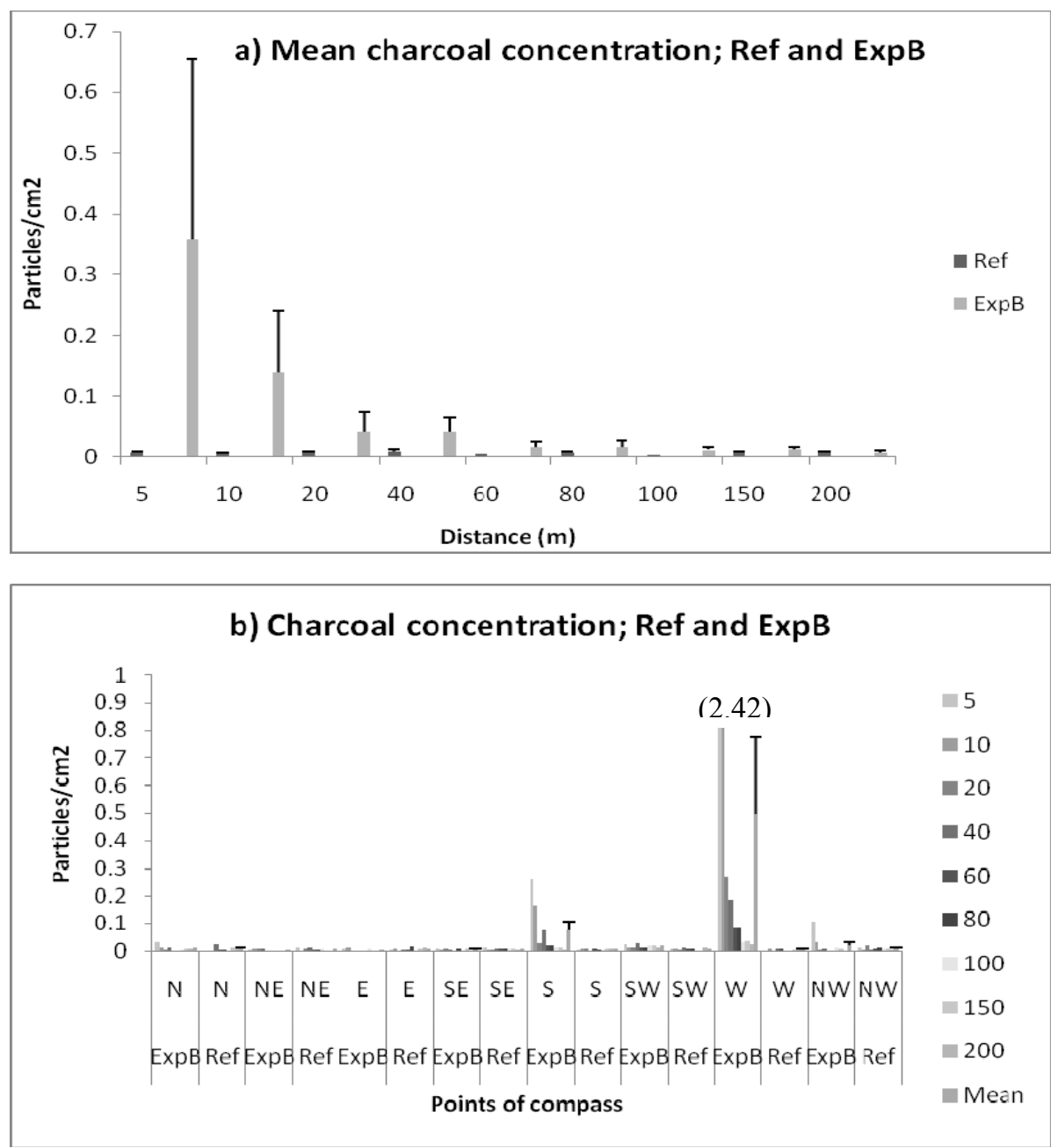

Figure 3. Concentrations of charcoal particles $/ \mathrm{cm}^{2}$ (all size classes) in the reference samples (Ref) and after two days of experimental burning (ExpB), a) Mean values at indicated distances from the hut (5 to $200 \mathrm{~m}$ ), showing that the particles were uniformly distributed before, but not after, the experimental burning

(Kolmogorov-Smirnov test; $\mathrm{D}_{\mathrm{Ref}}=0.303196$ and $\mathrm{D}_{\mathrm{ExpB}}=0.73624, \mathrm{D}_{0.001(2), 9}=0.60846$ ), b) Total values for indicated directions and distances. Vertical lines indicate standard errors $(+\mathrm{SE})$ for mean values. The number in brackets indicates the maximum concentration (2.42) for column $\operatorname{ExpB~W}$ at $5 \mathrm{~m}$.

\subsection{Adamvalldá Stállo Site}

\subsubsection{Charcoal Accumulation and Dispersal Pattern}

In total, 2361 macroscopic charcoal particles were found in the 42 samples of soil (each covering a $3.14 \mathrm{~cm}^{2}$ area) collected around the three Stállo foundations. Of these, $2244(95 \%)$ were $0.1-0.5 \mathrm{~mm}$ long $(\min .=5$, max. $=$ 176 , mean $=25.7 \pm 4.0)$ and $111(4.7 \%)$ were $0.5-1.0 \mathrm{~mm}$ long. Only six particles $(0.3 \%)$ were $>1.0 \mathrm{~mm}$ long, five of which were found within a distance of $5 \mathrm{~m}$ from the center stick and one at $20 \mathrm{~m}$. 
The charcoal concentrations in the soil samples from the Stállo settlement varied between 1.9 and 62.7 particles $/ \mathrm{cm}^{2}$, with a mean value of $17.9 \pm 2.3$ based on data from all sampling plots (Table 1). Over $94 \%$ of all charcoal was found within a radius of $40 \mathrm{~m}$ and $82 \%$ within $20 \mathrm{~m}$ from the center (Table 1). The mean concentration at $0 \mathrm{~m}$ was $36.2 \pm 10.7$ particles $/ \mathrm{cm}^{2}$, and there were more than 18 particles $/ \mathrm{cm}^{2}$ at all sampling positions $\leq 20 \mathrm{~m}$ from the center (Figure $4 \mathrm{a}$ ), although there were more particles at $10 \mathrm{~m}$ than at $5 \mathrm{~m}$. At $80 \mathrm{~m}$ (data from three transects), the mean accumulation was $7.3 \pm 2.1$ particles $/ \mathrm{cm}^{2}$. The charred particles were most abundant along the west transect $\left(43 \%\right.$ of the total, $20.5 \pm 4.6$ particles $\left./ \mathrm{cm}^{2}\right)$ and least abundant along the east transect $\left(19 \%\right.$ of the total, $14.83 \pm 1.7$ particles $/ \mathrm{cm}^{2}$; Figure $\left.4 \mathrm{~b}\right)$. The particles were not uniformly distributed in relation to distance from the center (KS test, $\mathrm{D}_{\mathrm{St}}=0.736002, \mathrm{D}_{0.001(2), 9}=0.60846$ ).
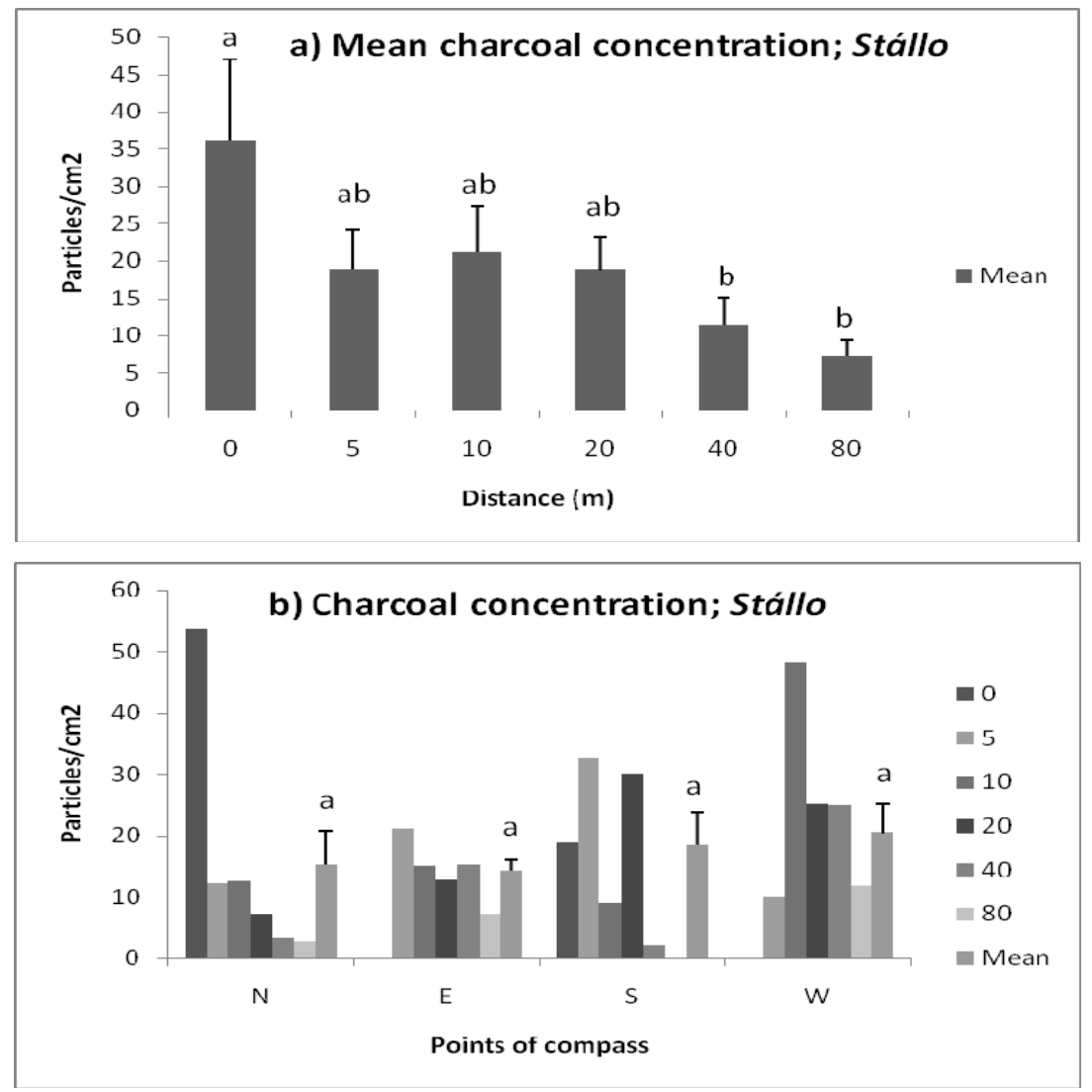

Figure 4. Concentrations of charcoal particles $/ \mathrm{cm}^{2}$ (all size classes) at the Stállo site: a) mean concentrations at indicated distances from the central point (mean values at 0 to $80 \mathrm{~m}$ ) and b) total concentrations at indicated directions and distances. Vertical lines indicate standard errors $(+\mathrm{SE})$ for mean values. Letters indicate that the means are not significantly different $\left(\mathrm{t}_{0.05}\right)$

Based solely on data for sampling distances common to all four transects (i.e. 5, 10, 20 and $40 \mathrm{~m}$; $\mathrm{n}=32$ ), which included $75 \%$ of all charcoal recorded, the mean concentration was $17.6 \pm 2.4$ (Table 1) and varied between $8.9 \pm 1.8$ (min.) and $27.1 \pm 5.4$ (max.) particles $/ \mathrm{cm}^{2}$ for the north and west transects, respectively. Calculations showed that the particles were not uniformly distributed at these distances (KS test, $\mathrm{D}_{\mathrm{St} 40}=0.975, \mathrm{D}_{0.001(2), 4}$ $=0.85047)$. There were significant differences in mean values between the 0 and $40 \mathrm{~m}$ and 0 and $80 \mathrm{~m}$ distances (t-test for paired data with unequal variance, $\mathrm{p}=0.05$ ), but no differences in the mean values between the directions (Figure $4 a$ and $b$ ).

\section{Discussion}

\subsection{Experimental Burning}

The amount of macroscopic charcoal found in the reference samples prior to the burning was low, considering that ice and snow had covered the lake for two months (Figure 3a and b). This charcoal probably derived from fires inside local houses, camp fires, snow mobiles, cars and some long distance sources. All of these particles belonged to the smallest class size and are not considered to have affected the results derived from the experimental burning. 
The amount of charcoal after the experimental burning was high and most particles were found close to the hut, although charcoal was also recorded at a distance of $200 \mathrm{~m}$. During the burning, the prevailing wind blew steadily from the east, resulting in an abundance of charcoal particles along the western transect at all distances, but with a clear decrease in numbers with increasing distance from the hut (Figure 3a and $b$ ). There were also, however, charcoal particles along the southern transect, probably because the wind changed direction from east to north during the night between days three and four (after the burning finished, but before the charred particle samples were collected). Although no burning was conducted during that time, it seems reasonable to believe that the charcoal recorded along the southern transect was released from the fabric of the hut and dispersed by the northern wind during the following night and morning. In addition, some particles may have derived from the clothes of the person responsible for monitoring the wind and temperature, because that person was inside the hut between the observations, and continuously exposed to charred particles from the fire during the burning. Charcoal may then have been released and dispersed along the south transect after completion of the monitoring as the wind gauge was located $10 \mathrm{~m}$ to the SSE (Figure 1).

Despite the time constraints, the experimental burning showed that even charcoal from hearths in huts can be widely dispersed and that the deposition pattern is highly dependent on the distance from the hearth and the wind conditions. Most of the charcoal was recorded within $40 \mathrm{~m}$ of the hut, although a few particles were found downwind at a distance of $200 \mathrm{~m}$. The statistical tests showed that the particles were unevenly distributed and there was a clear decrease in the number of particles with increasing distance from the hut, a pattern mirroring reductions in the amount of charcoal with increasing distance from the edges of burnt areas in field experiments with forest fires (Lynch et al., 2004). However, the experimental burning was performed on a frozen lake with no trees or other obstacles that could have affected the wind flow and thus the dispersal pattern. Thus, whilst it is possible to discuss the deposition pattern and use the particle concentrations observed following the experimental burning to calculate approximate amounts of charcoal that may have been deposited around a real Stállo settlement, one should be aware that many factors in mountainous terrain (such as trees and the local topography) could cause local patterns of charcoal dispersal and deposition to differ from those observed on flat ice.

\subsection{Charcoal Concentrations and Deposition at the Stállo Settlement}

The number of macroscopic charcoal particles recorded around the Stállo foundations in Adamvalldá at distances up to $80 \mathrm{~m}$ was surprisingly high. This suggests that charcoal produced during the settlement phase was still present in the topmost soil, and that charcoal is fairly resistant to oxidation, fragmentation and microbial activity in the area. Most of the detected charcoal particles, including the larger ones, were found within $20 \mathrm{~m}$ of the centre stick and their concentration decreased with increasing distance from the centre. Consequently, the dispersal pattern and distribution of charcoal particles at the Stállo site was very similar to the patterns found following the experimental burning, suggesting most of the charcoal recorded in the soil at the SMA 51 Stállo site was derived from hearth fires and not from burning vegetation around the settlements or from solitary tent hearths.

The microscopic charcoal recorded in the pollen analysis by Karlsson et al. (2007), which dated to the post-Stállo period, most likely derived from more recent fires in solitary tent hearths located near the small mire (Figure 2). This interpretation is also supported by the fact that the microscopic charcoal recorded in the pollen slides did not co-occur with major changes in vegetation that took place during the end of the Stállo period, ca. AD 1150 (Karlsson et al., 2007). Hence, the small mire was located too far away to register charcoal from the Stállo hearths at SMA 65, 103 and 51when they were in use, especially when the area was still forested because the trees would have restricted the dispersal of charcoal. In contrast, when the area became an open heath, charcoal from subsequent fires in solitary tent hearths located $100 \mathrm{~m}$ away, could have been carried further by the wind and deposited in the mire. However, secondary translocation of charcoal from the Stállo settlements to the mire at a later date cannot be totally ruled out (see below). It is also possible that some charcoal particles from the mire were lost during the chemical treatment of the pollen samples through acetolysis (Tinner \& Hu, 2003). Our results demonstrate that analysis of charcoal within $40 \mathrm{~m}$ of a hearth can provide strong evidence of burning at a settlement. However, there is a risk that a biological archive, like a mire, located close to a settlement may have been disturbed by people and/or animals at a later date.

\subsection{Charcoal Concentrations and Dispersal: Theory vs. Evidence}

From the restricted experimental burning, it can be concluded that the number of charcoal particles produced by a fire in a hut is rather large, since 0.07 particles $/ \mathrm{cm}^{2}$ were deposited per day (mean value, with 10 hours of burning) within $40 \mathrm{~m}$ of the hut. If we assume that people burnt wood in each Stállo hearth to cook food and 
provide heating for 10 hours every day, that they were present at the Stállo settlement for approximately 100 days per year and that all three huts were used simultaneously, the average amount of charcoal particles accumulated would have been approximately be $0.07 \times 100 \times 3=21 / \mathrm{cm}^{2}$ per year. The mean concentration of charcoal found in the soil within $40 \mathrm{~m}$ of the Adamvalldá settlement was 17.9 particles $/ \mathrm{cm}^{2}$. Hence, if the Stállo hearths in Adamvalldá were used in the same way as our experimental hearth, this indicates that the settlement was used for just ca. 85 days in total. This is, of course, not likely considering the evidence from extensive dating of charcoal from the hearths (Liedgren et al., 2007), and clear indications from detailed palaeoecological analyses of vast vegetation changes and deforestation at this site 1000 years ago (Karlsson et al., 2007). It is difficult to estimate how long the Stállo settlement was used before the lack of firewood forced the settlers to move, but if it was used for 30 or 50 years that would give values of over 600 or 1000 particles $/ \mathrm{cm}^{2}$, respectively. So why is the amount of charcoal so low at this Stállo site today?

In the experimental burning, all the macroscopic charcoal particles were preserved intact in the snow and they were collected soon after their dispersal. At the study site, the Stállo charcoal has been present in an aerated environment for around 1000 years so the low amount may be explained by long-term degradation, secondary transport through erosion and/or relocation to a greater depth in the soil. Long-term chemical degradation of macroscopic charcoal has probably occurred, with consequent changes in its characteristics over time (Czimczik et al., 2003, Hockaday et al., 2006, Ascough et al., 2011). Some charcoal may also have been degraded by soil microorganisms, like saprophytic fungi (Hockaday et al., 2006). Physical factors, such as frost, together with trampling by reindeer and humans could have caused substantial fragmentation of charcoal, and/or its secondary transport, especially of smaller fragments, by wind and water during and after the Stállo settlement period. The reduction in charcoal levels has probably been most severe in heavily used areas with substantial erosion around the huts where human activity was intense. This may explain why the amount of recorded macroscopic charcoal concentration was slightly lower at a distance of $5 \mathrm{~m}$ than at distances of 0 and $10 \mathrm{~m}$ from the central reference point (Figure 4a). After the Stállo period, the alpine heath was used by nomads for reindeer grazing so the Stállo charcoal would have been trampled for an extended period of time. New charcoal has also been produced by burning in solitary tent hearths. As the Adamvalldà area has been transformed from a birch forest into an open alpine heath, this has caused wind erosion and hence translocation of charcoal particles. In the springtime, fragmented microscopic particles could also have been transported by running water, both horizontally and vertically. It is thus likely that fragmented microscopic charcoal particles are present at greater depths in the soil (Carcaillet, 2001) and could have been detected by other methods than the one used here (see Kurth et al., 2006). Hence, from our calculations it seems that the amount of macroscopic charcoal particles produced during the Stállo period in sub-alpine and alpine areas has dramatically declined over time, probably due to various chemical and physical factors, but more research is needed to evaluate the magnitude and causes of this loss.

\subsection{Implications}

Consequently, the amount of macroscopic charcoal found at the Stállo site today is much lower than the theoretical amount calculated from the experimental burning results. Still, this small study shows that the amount of charcoal particles produced by burning in hearths is substantial and that the particles are fairly well preserved in the soil even after long periods of time. As most charcoal, $>90 \%$, was found within $40 \mathrm{~m}$ of the hearth in the experimental burning, it is important to ensure that any biological archive used to determine the origin of charcoal particles that may be associated with an ancient settlement in archaeological and vegetation history studies is located as close to the site of the settlement as possible. The dispersal pattern around a hearth seems to be characteristic, so it would be possible to use the observed pattern to determine the origin of soil charcoal in areas where natural fires have been rare. Many solitary tent hearths are located in association with alpine mires so it would be possible to verify their use through AMS dating of both charcoal found in hearths and peat. However, in boreal areas where fires have occurred frequently, this method is not feasible as old charcoal will have been combusted repeatedly and new charcoal will have been produced (Liedgren et al., 2007).

Even if the dispersal of macroscopic charcoal produced by hearths in huts is rather limited, the experimental burning also indicates that some charcoal may be widely dispersed in open terrain. The results obtained indicate that a settlement with three huts used for 100 days per year for 30 years would, on average, generate cumulative totals of approximately 58 and 32 particles $/ \mathrm{cm}^{2}$ in biological archives located 150 and $200 \mathrm{~m}$ from the settlement, respectively. These amounts of charcoal are low in comparison to the amounts released from natural fires and would not create any peak in charcoal accumulation rates calculated in fire ecology studies. However, they would contribute to the background influx of lake sediments and peat mires because this charcoal would probably not be degraded due to the anaerobic conditions in these archives, especially if the archives are located in the prevailing wind direction. Consequently, the interpretation of charcoal from biological archives must 
always be cautious. Anthropogenic charcoal from hearth fires in settlements used for just a few decades may contribute to the background charcoal influx in biological archives located up to $200 \mathrm{~m}$ from a settlement in an open environment. On the other hand, the lack of charcoal in the pollen slides from the small mire at Adamvalldá during the Stállo period reported by Karlsson et al. (2007) should not be interpreted as reflecting a total lack of burning in the area as the large amount of macroscopic charcoal in the soil around the Stállo settlements clearly showed.

\section{Conclusion}

The overall results from this macroscopic charcoal study suggest that: 1) the amount of charcoal dispersed from hearths in huts is sufficient for it to be detected in the vicinity of the settlement; 2) charcoal is mainly dispersed within $40 \mathrm{~m}$ of the hut; 3 ) charcoal produced in sub-alpine Stállo settlements 1000 years ago can still be found in the soil today, although the amount has been substantially reduced due to degradation, fragmentation and translocation; and 4) the distribution pattern, which shows a clear decrease in charcoal with increasing distance from the settlements, indicates that the charcoal mainly derived from fires in Stállo hearths. It can be concluded that in regions where natural fires are very rare, such as the sub-alpine and alpine areas of northern Scandinavia, macroscopic charcoal occurrences in association with archaeological settlements are strong indicators of anthropogenic fires. The charcoal dispersal pattern around settlements can also be used to evaluate the origin of charcoal in such regions, but it is important to ensure that any biological archive used to determine the origin of charcoal particles that may be associated with an ancient settlement in archaeological and vegetation history studies is located as close $(\leq 40 \mathrm{~m})$ to the site of the settlement as possible. However, some charcoal is dispersed at even greater distances so the interpretation of results of analyses of charcoal occurrences in biological archives and soils must always be cautious.

\section{Acknowledgements}

We wish to thank Ingela Bergman, Lars Östlund, Olle Zackrisson, Tom DeLuca and Mikael Ohlson for interesting discussions regarding charcoal occurrences and the analysis of such material, and two anonymous reviewers for providing constructive comments to improve the content. The manuscript has been linguistically corrected by Sees-editing Ltd, UK. The study was funded by the European Regional Development Fund.

\section{References}

Ali, A. A., Higuera, P. E., Bergeron, Y., \& Carcaillet, C. (2009). Comparing fire-history interpretations based on area, number and estimated volume of macroscopic charcoal in lake sediments. Quaternary Research, 72, 462-468. http://dx.doi.org/10.1016/j.yqres.2009.07.002

Ascough, P. L., Bird, M. I., Francis, S. M., Thornton, B., Midwood, A. J., Scott, A. C., \& Apperley, D. (2011). Variability in oxidative degradation of charcoal: Influence of production conditions and environmental exposure. Geochimica et Cosmochimita Acta, 75, 2361-2378. http://dx.doi.org/10.1016/j.gca.2011.02.002

Bennett, K. D., Simonson, W. D., \& Peglar, S. M. (1990). Fire and man in post-glacial woodlands of eastern England. Journal of Archaeological Science, 12, 635-642. http://dx.doi.org/10.1016/0305-4403(90)90045-7

Bergman, I., Östlund, L., Zackrisson, O., \& Liedgren, L. (2007). Stones in the snow: A Norse fur traders' road into Sami country. Antiquity, 81, 1-12.

Carcaillet, C. (2001). Are Holocene wood-charcoal fragments stratified in alpine and subalpine soils? Evidence from the Alps based on AMS ${ }^{14} \mathrm{C}$ dates. The Holocene, 11, 231-242. http://dx.doi.org/10.1191/095968301674071040

Carcaillet, C., Bergman, I., Delorme, S., Hörnberg, G., \& Zackrisson, O. (2007). Long-term fire frequency not linked to prehistoric occupations in northern Swedish boreal forest. Ecology, 88, 465-77. http://dx.doi.org/10.1890/0012-9658(2007)88[465:LFFNLT]2.0.CO;2

Clark, J. S. (1988). Particle motion and the theory of charcoal analysis: source area, transport, deposition and sampling. Quaternary Research, 30, 67-80. http://dx.doi.org/10.1016/0033-5894(88)90088-9

Clark, J. S., Lynch, J., Stocks, B. J., \& Goldhammer, J. G. (1998). Relationships between charcoal particles in air and sediments in west-central Siberia. The Holocene, 8, 19-29. http://dx.doi.org/10.1191/095968398672501165

Czimczik, C. I., Preston, C. M., Schmidt, W. I., \& Schultze, E. C. (2003). How surface fire in Siberian Scots pine forests affect soil organic carbon in the forest floor: Stocks, molecular structure and conversion to black carbon (charcoal). Global Biogeochemical Cycles, 17(1), 1020-1040. http://dx.doi.org/10.1029/2002GB001956 
Emanuelsson, M., \& Segerström, U. (1998). Forest grazing and outland exploitation during the Middle Ages in Dalarna, central Sweden: a study based on pollen analysis. In H. Andersson, L. Ersgård, \& E. Svensson (Eds), Outland use in preindustrial Europe. Lund Studies in Medieval Archaeology, 20, 80-94.

Emanuelsson, M. (2001). Settlement and land-use history in the central Swedish forest region. The use of pollen analysis in interdisciplinary studies. PhD-thesis, SLU, Umea, Sweden, Silvestria 23.

Froyd, C. A. (2006). Holocene fire in the Scottish Highlands: evidence from macroscopic charcoal records. The Holocene, 16, 235-49. http://dx.doi.org/10.1191/0959683606hl910rp

Granström, A. (1993). Spatial and temporal variation in lightning ignitions in Sweden. Journal of Vegetation Science, 4, 737-744. http://dx.doi.org/10.2307/3235609

Heinselman, M. L. (1981). Fire and succession in the conifer forest of northern North America. In D. C. West, H. H. Shugart, \& D. B. Botkin (Eds), Forest successions (pp. 374-405). New York: Springer Verlag.

Hellberg, E., \& Carcaillet, C. (2003).Wood anatomy of West European Betula; Quantitative descriptions and applications for routine identification in palaeoecological studies. Écoscience, 10, 370-379.

Hellberg, E. (2004). Historic variability of deciduous trees and deciduous forests in Northern Sweden - effects of forest fires, land use and climate. PhD-thesis, SLU, Umeå, Sweden, Silvestria 308.

Higuera, P. E., Peters, M. E., Brubaker, L. B., \& Gavin, D. G. (2007). Understanding the origin and analysis of sediment-charcoal records with a simulation model. Quaternary Science Reviews, 26, 1790-1809. http://dx.doi.org/10.1016/j.quascirev.2007.03.010

Hockaday, W. C., Grannas, A. M., Kim, S., \& Hatcher, P. G. (2006). Direct molecular evidence for the degradation and mobility of black carbon in soils from ultrahigh-resolution mass spectral analysis of dissolved organic matter from a fire-impacted forest soil. Organic Geochemistry, 37, 501-510. http://dx.doi.org/10.1016/j.orggeochem.2005.11.003

Hörnberg, G., Bohlin, E., Hellberg, E., Bergman, I., Zackrisson, O., Olofsson, A., Wallin, J. E., \& Passe, T. (2006). Effects of Mesolithic hunter-gatherers on local vegetation in a non-uniform glacio-isostatic land uplift area, northern Sweden. Vegetation History and Archaeology, 15, 13-26. http://dx.doi.org/10.1007/s00334-005-0006-x

Hörnberg, G., Östlund, L., Zackrisson, O., \& Bergman, I. (1999). The genesis of two Picea-Cladina forests in northern Sweden. Journal of Ecology, 87, 800-814. http://dx.doi.org/10.1046/j.1365-2745.1999.00399.x

Hörnberg, G., Staland, H., Nordström, E. M., Korsman, T., \& Segerström, U. (2012). Fire as an important factor for the genesis of boreal Picea abies swamp forests in Fennoscandia. The Holocene, 22, 203-214. http://dx.doi.org/10.1177/0959683611414936

Karlsson, H., Hörnberg, G., Hannon, G., \& Nordström, E. M. (2007). Long-term vegetation changes in the northern Scandinavian forest line; a human impact-climate synergy?. The Holocene, 17, 447-456. http://dx.doi.org/10.1177/0959683607073277

Karlsson, H., Shevtsova, A., \& Hörnberg, G. (2009). Vegetation development at a mountain settlement site in the Swedish Scandes during the late Holocene - palaeoecological evidence for human induced deforestation. Vegetation History and Archaeobotany, 18, 297-314. http://dx.doi.org/10.1007/s00334-008-0207-1

Kjellström, R. (1983). Staloproblemet i samisk historia. In Kjelland, A., Sandnes, J. and J. Østerlie, I. (Eds), Folk og resurser $i$ nord. Foredrag fra Tronheimsymposiet om midt- og nordskandinavisk kultur 1982. University of Trondheim, NLHT, Tapir, (in Swedish).

Kurth, V. J., MacKenzie, M. D., \& DeLuca, T. H. (2006). Estimating charcoal content in forest mineral soils. Geoderma1, 37, 135-139. http://dx.doi.org/10.1016/j.geoderma.2006.08.003

Larsson, B. (1995). Svedjebruk och röjningsbränning $i$ Norden. Skrifter om skogs- och lantbrukshistoria, Kungliga Skogs- och Lantbruksakademien, Nordiska Museet och Sveriges Lantbruksuniversitet. Nordiska Museets Förlag, Stockholm.

Liedgren, L., \& Bergman, I. (2009). Aspects of the construction of prehistoric Stállo-foundations and Stállo-buildings. Acta Borealia, 26, 3-26. http://dx.doi.org/10.1080/08003830902951516

Liedgren, L., \& Östlund, L. (2011). Heat, smoke and fuel consumption in a high mountain Stállo-hut, northern Sweden - Experimental burning of fresh birch wood during winter. Journal of Archaeological Science, 38, 903-912. http://dx.doi.org/10.1016/j.jas.2010.11.020 
Liedgren, L. (2004). Utgrävning av härdar och stalotomter i Adamvalldáområdet, Arjeplog, 2003. Silvermuseet Rapport 37.

Liedgren, L., Bergman, I., Hörnberg, G., Zackrisson, O., Hellberg, E., Östlund, L., \& DeLuca, T. (2007). Radiocarbon dating of prehistoric hearths in alpine northern Sweden: problems and possibilities. Journal of Archaeological Sciences, 34, 1276-1288. http://dx.doi.org/10.1016/j.jas.2006.10.018

Lynch, J. A., Clark, J. S., \& Stocks, B. J. (2004). Charcoal production, dispersal and deposition from the Port Providence experimental fire: interpreting fire regimes from charcoal records in boreal forests. Canadian Journal of Forest Research, 34, 1642-56. http://dx.doi.org/10.1139/x04-071

Mellars, P. (1976). Fire ecology, animal populations and man: a study of some ecological relationships in prehistory. Proceedings of the Prehistoric Society, 42, 15-45.

Mooney, S. D., \& Tinner, W. (2011). The analysis of charcoal in peat and organic sediments. Mires and Peat 7 , 1-18. http://www.mires-and-peat.net/

Mulk, I. M. (1994). Sirkas - a Sami hunting society in translation AD 1 - 1600. Studia Archaeological Universitatis Umensis 6. PhD-thesis, Department of Archaeology, University of Umeå.

Niklasson, M., \& Granström, A. (2000). Numbers and sizes of fires: Long-term spatially explicit fire history in a $\begin{array}{lllll}\text { Swedish boreal } & \text { landscape. } & \text { Ecology } & \text { 1484-99. }\end{array}$ http://dx.doi.org/10.1890/0012-9658(2000)081[1484:NASOFL]2.0.CO;2

Ohlson, M., \& Tryterud, E. (2000). Interpretation of the charcoal record in forest soils: forest fires and their production and deposition of macroscopic charcoal. The Holocene, 10, 519-525. http://dx.doi.org/10.1191/095968300667442551

Ohlson, M., Dahlberg, B., Økland, T., Brown, K. J., \& Halvorsen, R. (2009). The charcoal and carbon pool in boreal forests. Nature Geoscience, 2, 692-695. http://dx.doi.org/10.1038/ngeo617

Patterson, W. A., Edwards, K. J., \& Maguire, D. J. (1987). Microscopic charcoal as a fossil indicator of fire. Quaternary Science Reviews, 6, 3-23. http://dx.doi.org/10.1016/0277-3791(87)90012-6

Payette, S., \& Filion, L. (1993). Origin and significance of subarctic patchy podsolic soils and palaeosols. Arctic and Alpine Research, 25, 267-275. http://dx.doi.org/10.2307/1551912

Preston, C. M., \& Schmidt, M. W. I. (2006). Black (pyrogenic) carbon: a synthesis of current knowledge and uncertainties with special consideration of boreal regions. Biogeoscience, 3, 397-420. http://dx.doi.org/10.5194/bg-3-397-2006

Schalachter, K. J., \& Horn, S. P. (2010). Sample preparation methods and replicability in macroscopic charcoal analysis. Journal of Paleolimnology, 44, 701-708. http://dx.doi.org/10.1007/s10933-009-9305-z

Segerström, U., von Stedingk, H., \& Hörnberg, G. (2008). Long-term sustainability of a northern boreal deciduous swamp forest in northern Sweden: succession in the absence of fire. The Holocene, 18, 1113-1122. http://dx.doi.org/10.1177/0959683608093539

Sergant, J., Crombé, P., \& Perdaen, Y. (2006). The 'invisible' hearths: a contribution to the discernment of Mesolithic non-structured surface hearths. Journal of Archeological Science, 7, 999-1007. http://dx.doi.org/10.1016/j.jas.2005.11.011

Sjörs, H. (1999). The background: geology, climate and zonation. Acta Phytogeographica Suecica, 84, 5-14.

Staland, H., Salmonsson, J., \& Hörnberg, G. (2011). A thousand years of human impact in the northern Scandinavian mountain range: Long-lasting effects on forest lines and vegetation. The Holocene, 21, 379-392. http://dx.doi.org/10.1177/0959683610378882

Théry-Parisot, I., Chabal, L., \& Chrzavzez, J. (2010). Anthracology and taphonomy. From wood gathering to charcoal analysis. A review of the taphonomic processes modifying charcoal assemblages in archaeological contexts. Palaeogeography, Palaeoclimatology, Palaeoecology 291, 142-153. http://dx.doi.org/10.1016/j.palaeo.2009.09.016

Tinner, W., \& Hu, F. S. (2003). Size parameters, size class distribution and area-number relationship of microscopic charcoal: Relevance for fire reconstruction. The Holocene, 13, 499-505. http://dx.doi.org/10.1191/0959683603hl615rp

Wallin, J. E., \& Segerström, U. (1994). Natural resources and agriculture during the Iron Age in Ostrobothnia, western Finland, investigated by pollen analysis. Vegetation History and Archaeobotany, 5, 301-312. 
Whitlock, C., \& Millspraugh, S. H. (1996). Testing the assumption of fire-history studies: an examination of modern charcoal accumulation. The Holocene, 6, 7-15. http://dx.doi.org/10.1177/095968369600600102

Zackrisson, O. (1977). Influence of forest fire on the north Swedish boreal forest. Oikos, 29, 22-33. http://dx.doi.org/10.2307/3543289

Zar, J. H. (2010). Biostatistical Analysis (fifth edition). New Jersey: Pearson International Edition, Prentice Hall Inc. 